\title{
Selected Wood Properties of Prunus Africana (Hook) Grown in Kenya as Possible Reasons for its High Natural Durability
}

\section{Odabrana svojstva drva Prunus africana iz Kenije i mogući razlozi njegove velike prirodne trajnosti}

\author{
Original scientific paper • Izvorni znanstveni rad \\ Received-prispjelo: 31. 7. 2012. \\ Accepted-prihvaćeno: 15. 2. 2013. \\ UDK: $630 * 812 ; 674.031 .734 .4$ \\ doi:10.5552/drind.2013.1238
}

\begin{abstract}
Studies were carried out on the influence of Prunus africana heartwood extractives on the growth of selected wood decay fungi. Also, wood chemical and mineral content, dimensional stability and anatomical features of P. africana were studied. Heartwood extractives were tested in 100 ppm and 500 ppm concentrations on white, brown rot, and blue stain fungi and growth inhibition was determined as a factor of time. Dimensional stability was determined by computing the swelling coefficient after the blocks were saturated with moisture. Klason lignin, Kürschner cellulose, extractive and ash contents were determined by standard procedures. Infrared analyses were performed using Perkin Elmer FTIR spectrometer. Microscopic examination was performed using an environmental scanning electron microscope. The results showed that the wood is dimensionally stable, and contains $12.7 \%$ extractives, $37.6 \%$ cellulose and $30.4 \%$ lignin. Extractives deposited in vessels are highly soluble in dichloromethane and mainly composed of terpenes. Extractives were able to inhibit the growth of white rot fungi Coriolus versicolor, brown rot fungi Poria placenta and blue stain fungi Aureobasidium pullulans at different concentrations tested and could explain the high durability of Prunus africana wood species.
\end{abstract}

Key words: Prunus africana, heartwood, extractives, fungi, inhibition

SAŽETAK • Cilj rada bio je istražiti utjecaj ekstraktivnih tvari u drvu Prunus africana na pojavu i razvoj određenih vrsta gljiva koje uzrokuju trulež. Također, analiziran je kemijski i mineralni sastav drva P. africana, njegova dimenzijska stabilnost $i$ anatomska obilježja. Ekstraktivi iz drva srži testirani su u koncentraciji 100 ppm i 500 ppm na gljive bijele truleži, smeđe truleži i plavila, a inhibicija rasta određena je kao faktor vremena. Dimenzijska je stabilnost određena izračunavanjem koeficijenta bubrenja nakon što su uzorci natopljeni vodom do zasićenja. Klason lignin, Kürschner celuloza, ekstraktivi i sastav pepela određeni su standardnim postupcima.

\footnotetext{
${ }^{1}$ Authors are senior lecturer, lecturer and senior lecturer at Department of Forestry and Wood Science, Chepkoilel University College, Moi University, Eldoret, Kenya. ${ }^{2}$ Authors are professors at Laboratoire d'Etudes et de Recherche sur le Matériau Bois, Nancy-Université, Vandoeuvre les Nancy, France.

Autori su viši predavač, predavač i viši predavač Odjela šumarstva i znanosti o drvu, Chepkoilel University College, Moi University, Eldoret, Kenija. ${ }^{2}$ Autori su profesori u Laboratoire d'Etudes et de Recherche sur le Matériau Bois, Nancy-Université, Vandoeuvre les Nancy, Francuska.
} 
Infracrvena analiza provedena je upotrebom FTIR spektrometra Perkin Elmer. Mikroskopska istraživanja provedena su uz primjenu elektronskog mikroskopa. Rezultati su pokazali da je drvo P. africana dimenzijski stabilno, da sadržava 12,7\% ekstraktivnih tvari, 37,6\% celuloze i 30,4\% lignina. Ekstraktivne tvari pohranjene u trahejama vrlo su topljive u diklormetanu i uglavnom su sastavljene od terpena. Ekstraktivi su bili sposobni spriječiti razvoj gljive bijele truleži Coriolus versicolor, gljive smeđe truleži Poria placenta i gljive plave truleži Aureobasidium pullulans pri različitim koncentracijama, čime se može objasniti vrlo velika prirodna trajnost te vrste drva.

Ključne riječi: Prunus africana, drvo srži, ekstraktivne tvari, gljive, sprečavanje rasta gljiva

\section{INTRODUCTION}

\section{UVOD}

Prunus africana (Hook) occurs widely in tropical Africa. In Kenya, the plant is widely found in natural indigenous forests of Central and Rift Valley provinces. Wood of $P$. africana is widely used in Kenya for the construction of bridges and railway sleepers due to its high natural durability (Mburu, 2007). The heartwood is dark brown in color and described as resistant to termites and fungi (Mburu, 2007). Depletion of this wood species has raised concern in the Forestry Sector due to illegal exploitation evident in some parts of the country (Hitimana, 2000). In spite of the logging ban by the Kenyan government, farmers are encouraged to domesticate $P$. africana, a high value tree species, to ensure its continued existence. Traditionally, water extractives of $P$. africana bark are used orally to treat benign enlargement of the prostate gland in man (Bombardelli and Morazzoni, 1997; Stewart et al., 2003; Catalano et al., 1984; Breza at al., 1998). Pentacyclic triterpenes (oleanolic and ursolic acids) are believed to inhibit the activity of glucosyl-transferase, an enzyme involved in the inflammation process (Dufour et al., 1984; Bassi et al,. 1987; Barlet et al., 1990; Bombardelli and Morazzoni, 1997).

There is no reported data on the influence of $P$. africana extractives on specific wood destroying fungi by taking time of inhibition as a factor. Similarly, other factors that influence durability of wood such as chemical composition and anatomical features have not been fully investigated. This study aimed at providing important technological information on $P$. africana wood and testing growth inhibition of aggressive white rot fungi, Coriolus versicolor, brown rot fungi Poria placenta and coloration fungi Aureobasidium pullulans by heartwood extractives.

\section{MATERIALS AND METHODS} 2. MATERIJALI I METODE

\subsection{Soxhlet extraction \\ 2.1. Ekstrakcija soxhleta}

Mature $P$. africana trees growing in Kimondi, Kapsabet forest, Kenya were sampled, felled and wood sawn into blocks measuring $5 \mathrm{~mm} \times 20 \mathrm{~mm} \times 25 \mathrm{~mm}$. Heartwood and sapwood blocks, air dried to approximately $18 \% \mathrm{MC}$, were separately ground to fine powder, passed through a 115 -mesh sieve and dried at $60^{\circ} \mathrm{C}$ to constant weight and $12 \% \mathrm{MC}$ before extraction. Drying at $60{ }^{\circ} \mathrm{C}$ instead of $103{ }^{\circ} \mathrm{C}$ has been shown to minimize extractive degradation (Neya et al., 2004).
Hexane, acetone, dichloromethane, water and a mixture of toluene/ethanol at the ratio of $2: 1(\mathrm{v} / \mathrm{v})$ were used successively for soxhlet extraction of $50 \mathrm{~g}$ sample each for 15 hours at a rate of about 10-12 cycles per hour and replicated three times.

\subsection{Fungal growth inhibition}

2.2. Sprečavanje rasta gljiva

Mycelium was grown in $9 \mathrm{~cm}$ diameter Petri dishes filled with $20 \mathrm{ml}$ of malt-agar sterilized medium, prepared by mixing $20 \mathrm{~g}$ of malt and $40 \mathrm{~g}$ of agar in one liter of distilled water containing $100 \mathrm{ppm}$ or $500 \mathrm{ppm}$ of heartwood extract only. Plates were inoculated by placing a small portion of a malt- agar freshly grown fungal colony of C. versicolor, P. placenta or A. pullulans at the centre of each petri dish and cultures were maintained at $22{ }^{\circ} \mathrm{C}$ and $70 \%$ relative humidity. Growth was evaluated by measuring the mean of two perpendicular diameters of the colony every two days. Inhibition was computed using equation (1), when the diameter of control culture filled the petri-dish:

Growth inhibition $(\%)=100 \times\left(1-d_{2} / d_{1}\right)$

Where $d_{2}$ is the diameter of the control culture and $d_{1}$ the diameter of the extract culture.

\subsection{Determination of dimensional stability}

2.3. Određivanje dimenzijske stabilnosti

Twenty four specimens of $P$. africana were cut into regular blocks of $60 \mathrm{~mm} \times 20 \mathrm{~mm} \times 20 \mathrm{~mm}(l, r, t)$ with the surfaces smoothened using hand planer, dried to constant weight and their lineal dimensions measured to the nearest $0.01 \mathrm{~mm}$ using veneer callipers for the determination of initial volume $\left(V_{1}\right)$. The blocks were put in desiccators containing saturated copper sulphate solution and internal relative humidity greater than $80 \%$. The weights of the blocks were measured every two days until stabilization. The dimensions were measured along the initial axes and used to compute the swollen volume $\left(V_{2}\right)$ and swelling coefficient $(S)$ using the formula:

$$
S(\%)=\frac{V_{2}-V_{1}}{V_{1}} \times 100
$$

\subsection{Chemical analysis and composition}

\subsection{Kemijska analiza i sastav}

Heartwood powder was soxhlet extracted in series with ethanol and toluene/ethanol mixture at the ratio of $1: 2$ for 8 hours, then dried at $103{ }^{\circ} \mathrm{C}$. Approximately $500 \mathrm{mg}$ of extractive-free dry powder $\left(\mathrm{m}_{2}\right)$ was introduced in $10 \mathrm{ml}$ of $72 \%$ concentrated sulphuric acid at room temperature, stirred for 4 hours then diluted with $240 \mathrm{ml}$ of distilled water and heated at 100 
${ }^{\circ} \mathrm{C}$ for 4 hours in an oil bath. The solution was left for 25 minutes to cool, filtered through a Buchner funnel, rinsed with hot water at $70{ }^{\circ} \mathrm{C}$ and the residue dried at $103{ }^{\circ} \mathrm{C}$ to constant weight $\left(m_{1}\right)$. Klason lignin $(K L)$ content was calculated using the formula:

$$
K L(\%)=\frac{m_{1}}{m_{2}} \times 100
$$

Another heartwood powder sample was prepared by grinding, passed through 115-mesh sieve, soxhlet extracted in series with ethanol and toluene/ethanol mixture at the ratio of 1:2 for 8 hours, then dried at $103{ }^{\circ} \mathrm{C}$. Ten grams of extractive free dry heartwood powder was refluxed three times in a 1:4 volume mixture of concentrated nitric acid and ethyl alcohol for 1 hour, the residue washed, dried and weighed as Kürschner cellulose. An additional one gram of dried heartwood powder $\left(m_{0}\right)$ was heated in a furnace at $500{ }^{\circ} \mathrm{C}$ for 4 hours and ash generated weighed $\left(m_{\mathrm{a}}\right)$, and then percent ash content determined from the ratio $m_{\mathrm{a}}$ to $m_{0}$.

\subsection{Anatomical and infrared analysis \\ 2.5. Anatomska i infracrvena analiza}

An environmental scanning electron microscope (ESEM Quanta 200) was used to examine microtomed transverse surface of heartwood test specimen and photomicrographs taken at different magnifications. The transverse surface was clearly marked to enable observation of the same area before and after extraction. Nine mg of dichloromethane heartwood extract was mixed homogeneously with $300 \mathrm{mg} \mathrm{KBr}$ and pressed at 450 bars for 5 minutes to form pellets and analyzed using Perkin Elmer FTIR spectrometer, SPECTRUM 2000 with spectra recorded on a wave range of $400 \mathrm{~cm}^{-1}$ to $4000 \mathrm{~cm}^{-1}$.

\section{RESULTS}

\section{REZULTATI}

\subsection{Amount of wood extractives and their effect} on fungal growth

3.1. Količina ekstraktivnih tvari u drvu i njihov utjecaj na razvoj gljiva

Table 1 shows the amount of extractives in the heartwood and sapwood of $P$. africana through series extraction on the same batch of wood powder with different solvents of increasing polarity in the listed order.

Heartwood hexane extraction recorded the lowest percentage of $0.3 \%$ extract followed by dichloromethane $0.4 \%$. Extract content of acetone, toluene/ethanol and water was above $3 \%$. Water leads with the highest extract content of more than $5 \%$. The naturally durable heartwood (Mburu, 2007) contained higher amount of extractives than the perishable sapwood, and it was therefore used for evaluation of durability. Figure 1 shows that heartwood extractives inhibited fungal growth and that the effect depended on the type of extract used and the concentration levels. Total growth inhibition was observed for the three tested fungi at concentration levels of $500 \mathrm{ppm}$ dichloromethane extract. Toluene/ethanol and acetone extracts showed partial inhibition for the three fungi. Water extracts presented high inhibition activities at 500 ppm, while lower concentrations of $100 \mathrm{ppm}$ lead to partial inhibition.
Table 1 Percent yield of wood extractives from P. africana heartwood and sapwood removed by different solvents Tablica 1. Količina ekstraktivnih tvari u drvu srži i bjeljike izdvojena različitim otapalima

\begin{tabular}{|l|c|c|}
\hline \multirow{2}{*}{ Solvent / Otapalo } & \multicolumn{2}{|c|}{$\begin{array}{c}\text { Amount of extractive, \% } \\
\text { Količina ekstraktivnih tvari, \% }\end{array}$} \\
\cline { 2 - 3 } & $\begin{array}{c}\text { Heartwood } \\
\text { Drvo srži }\end{array}$ & $\begin{array}{c}\text { Sapwood } \\
\text { Drvo bjeljike }\end{array}$ \\
\hline Hexane / heksan & 0.3 & 0.3 \\
\hline $\begin{array}{l}\text { Dichloromethane } \\
\text { diklormetan }\end{array}$ & 0.4 & 0.4 \\
\hline Acetone / aceton & 3.0 & 2.9 \\
\hline $\begin{array}{l}\text { Toluene/Ethanol } \\
\text { toluen/etanol }\end{array}$ & 3.4 & 3.0 \\
\hline Water / voda & 5.6 & 5.1 \\
\hline Total / ukupno & 12.7 & 11.7 \\
\hline
\end{tabular}

Development of the mycelium on the malt-agar medium treated with toluene/ethanol, acetone or water extracts started after some inhibition period compared to that of the control. The period of mycelia growth inhibition increased with extract concentration for all the three test fungi. During this period, activity of the fungus was detected by formation of a colored area around the fungal inoculate with coloration increasing with the concentration of the extractive. Dichloromethane heartwood extracts showed higher growth inhibition to the three fungi than toluene/ethanol and acetone heartwood extractives even at low concentration. A. pullulans, which is a coloration fungi, showed the least resistance against all extractives, compared to $C$. versicolor and $P$. placenta white rot and brown rot fungi respectively.

\subsection{Chemical composition \\ 3.2. Kemijski sastav}

The results of chemical analysis of wood showed that heartwood contains a relatively high lignin content, and low hemicelluloses and cellulose contents. Lignin has a complex, non-repetitive three-dimensional structure, which makes it resistant to attack by numerous micro-organisms. The chemical composition of P. africana heart wood in percentage was lignin 30.4, cellulose 37.6 , hemicelluloses 18.5 , extractives 12.7 and ash 0.8 .

FTIR spectrum for $P$. africana dichloromethane heartwood extractives is presented in Figure 2. Transmittance $(\% T)$ Signals at $1690 \mathrm{~cm}^{-1}$ and $2600 \mathrm{~cm}^{-1}$ (broad absorption) are characteristic of carbonyl and hydroxyl groups respectively of carboxylic acid function. Hydroxyl groups of sugar unit appear at $3400 \mathrm{~cm}^{-1}$, while strong absorption at $2860 \mathrm{~cm}^{-1}$ is characteristic of $\mathrm{C}-\mathrm{H}$ vibrations present in aliphatic structure of terpenes (Catalano et al., 1984).

\subsection{Anatomical characteristics and dimensional stability}

3.3. Obilježja anatomske građe i dimenzijska stabilnost

Heartwood features of $P$. africana are highlighted in Figure 3 manifesting a radial arrangement of solitary, paired or clustered vessels of up to 5 elements and 

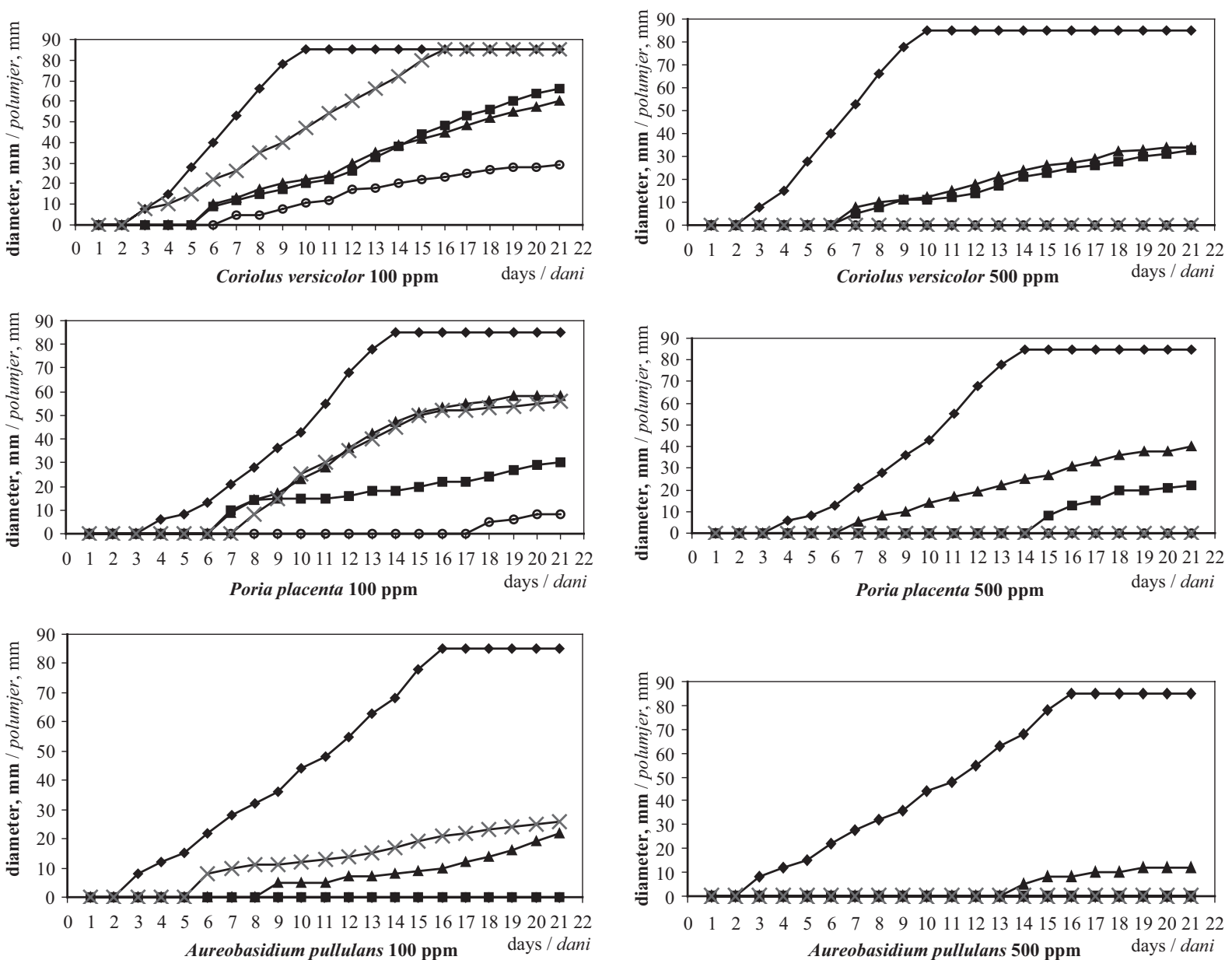

Figure 1 Inhibition of C. versicolor, P. placenta and A. pullulans growth by P. africana heartwood extractives from different solvents

Slika 1. Usporenje rasta gljiva C. versicolor, P. placenta i A. pullulans uz pomoć ekstraktivnih tvari dobivenih različitim otapalima iz srži drva P. africana

ranging in diameter between $50 \mu \mathrm{m}$ and $150 \mu \mathrm{m}$. Abundant extractive deposits, thick-walled fibers measuring $10 \mu \mathrm{m}$ and $30 \mu \mathrm{m}$, multiseriate rays 3 to 6 cells wide and 15 cells high, and low proportion of parenchyma cells associated with vessels characterize the cellular structure of the wood.
Most of the extractives deposited in the heartwood vessels were removed during extraction (Figure 3 (c) and (d)) and those from dichloromethane showed higher inhibition rate against growth of fungi indicating that extractives deposited in the vessels and rays contribute to the reported natural durability of $P$. afri-

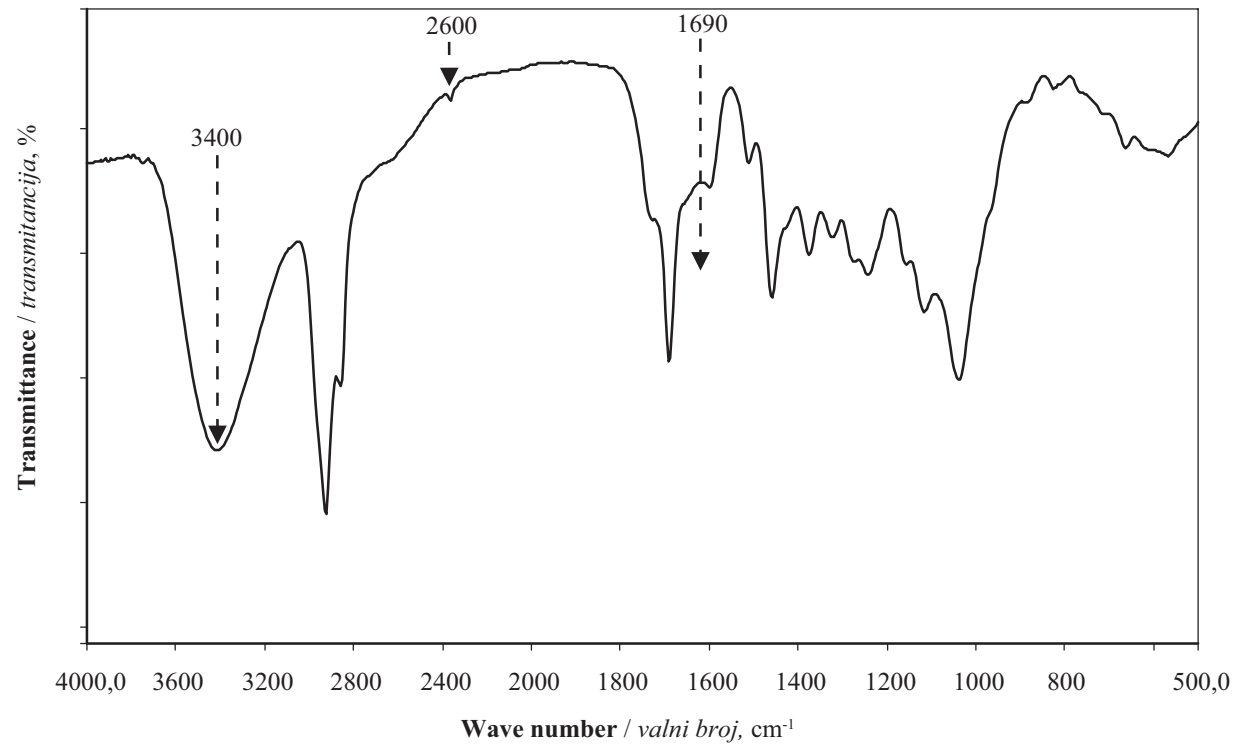

Figure 2 FTIR spectrum of $P$. africana dichloromethane heartwood extractives

Slika 2. FTIR spektar ekstraktivnih tvari dobivenih iz srži drva $P$. africana primjenom diklormetana kao otapala 
cana wood. Additionally, the relatively low mean swelling coefficient of $4.5 \%$ indicates that P.africana heartwood is dimensionally stable since it picks less moisture. This partially explains inhibition of fungal growth by heartwood extractives and contribution to the high natural durability of this species even in the outdoor use.

\section{DISCUSSION}

4. RASPRAVA

\subsection{Wood extractives and their effect on fungal} growth

4.1. Ekstraktivne tvari iz drva i njihov utjecaj na razvoj gljiva

The observed initial inhibition and subsequent fungal proliferation in the second and third week can be associated with detoxification of the agar medium by fungal enzymes (Neya et al., 2004). This indicates that only toluene/ethanol, acetone and water heartwood

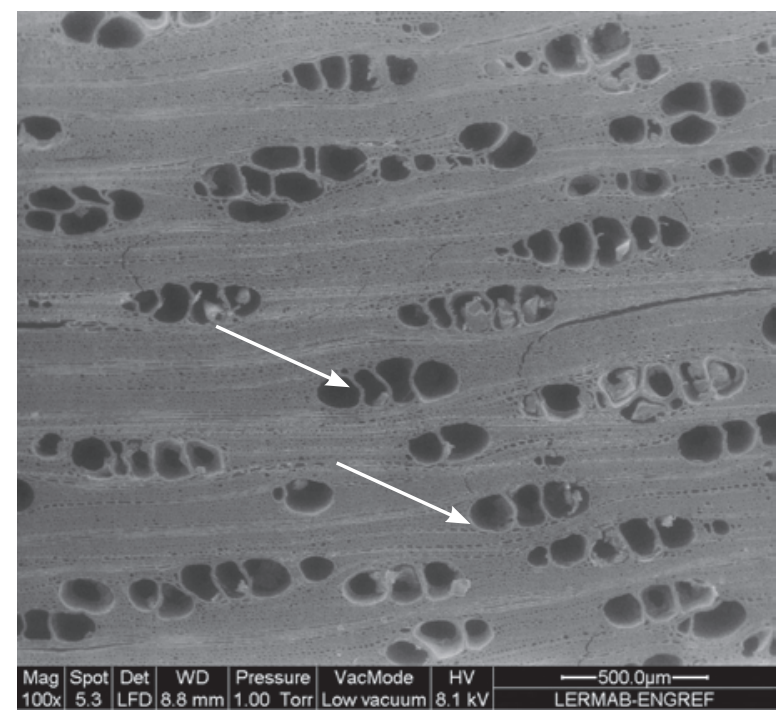

a) Radial arrangement of vessels

a) Radijalni raspored traheja

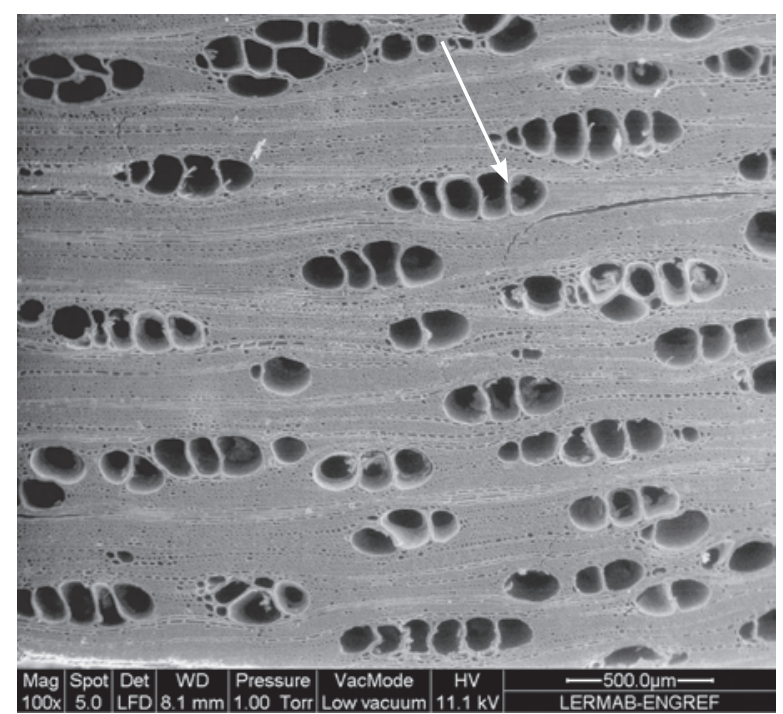

c) Vessels after extraction

c) Traheje nakon ekstrakcije extracts have inhibitory rather than toxicity properties. $P$. africana recorded high quantities of heartwood extracts at $12.7 \%$ and as described in the literature of other tropical species, may be one of the reasons of high natural durability (Neya et al., 2004).

Since dichloromethane extractives inhibited the growth of fungi more than acetone, toluene/ethanol and water extracts, it indicates that extractives deposited in the vessels and rays also contribute to the reported natural durability of $P$. africana wood. The observed dimensional stability is linked to lower uptake of water, which can enhance natural durability of this species even in outdoor use.

\subsection{Chemical composition and anatomical characteristics \\ 4.2. Kemijski sastav i anatomska obilježja}

Heartwood contains a relatively high lignin content, and low hemicelluloses and cellulose contents. The only organisms capable of mineralizing lignin into

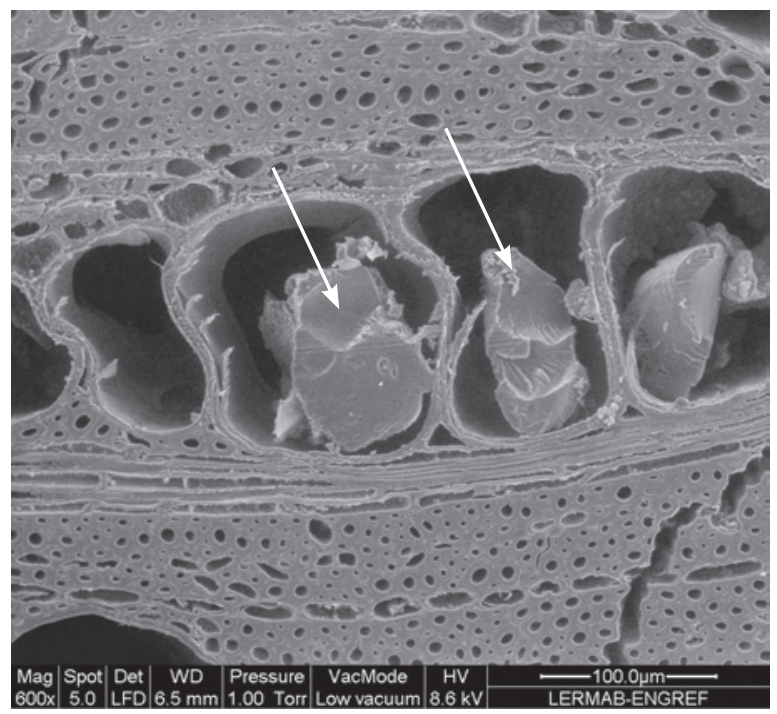

b) Extract deposits in vessels

b) Naslage ekstraktivnih tvari u trahejama

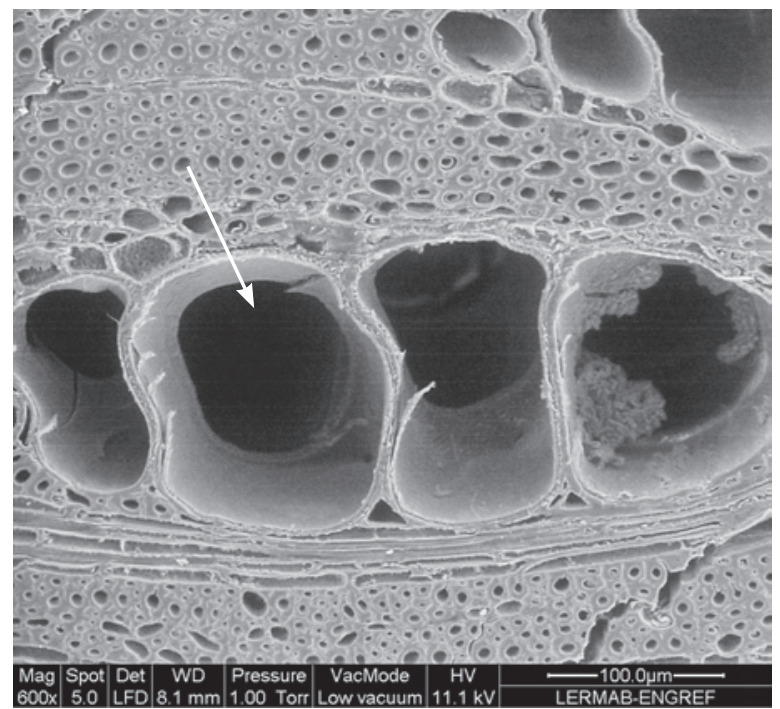

d) Vessels with extract deposit removed

d) Traheje nakon izdvajanja naslaga ekstraktivnih tvari

Figure 3 ESEM analysis of a transverse section of $P$. africana before and after dichloromethane extraction

Slika 3. Analiza ESEM poprečnog presjeka drva $P$. africana prije i nakon ekstrakcije diklormetanom 
water and carbon dioxide are white-rot fungi (Anke et al., 2006) due to its complex, non-repetitive three-dimensional structure. The high lignin content partly explains high resistance to the tested fungi species and hence the high natural durability of $P$. Africana (Mburu, 2007). The presence of oleanolic and ursolic acid and associated antifungal activities is consistent with previous findings on these extractives (Becker et al., 2005; Deepak and Handa, 2000). Saponins derived from oleanolic acid are also described to possess antifungal properties against phytopathogenic fungi explaining the durability of heartwood to fungal degradation (Escalente et al., 2002).

\section{CONCLUSION}

\section{ZAKLJUČAK}

The results showed that the wood of $P$. africana is dimensionally stable, and contains a high amount of extractives and lignin, which may partly explain its high durability in outdoor use. Extractives deposited in wood vessels and rays are highly soluble in dichloromethane and also contain terpenes, as indicated by FTIR spectra measurements. Terpenes, which possess antifungal properties, may explain the high fungal growth inhibition of heartwood extractives against C. versicolor, $P$. placenta and A. pullulans in a sterile chamber. Different heartwood extractives were able to inhibit the growth of all test fungi at different concentrations tested. Inhibition period before mycelia growth increased with extract concentration while the rate of growth increased with time after detoxification of malt-agar by fungi. The heartwood extracts could be at the origin of the reported heartwood durability of P.africana.

\section{Acknowledgement - Zahvala}

We acknowledge financial support from the French Government through its embassy in Nairobi Kenya to the first author while undertaking his Doctoral studies in Nancy I University. We also gratefully acknowledge the scientific visit grant for the same author from Nancy 2 during the 2010/2011 academic year.

\section{REFERENCES}

\section{LITERATURA}

1. Anke, H.; Roland, W.; Weber, S., 2006: White-rots, chlorine and the environment - a tale of many twists. Mycologist 20(3): 83-89

http://dx.doi.org/10.1016/j.mycol.2006.03.011.

2. Barlet, A.; Albrecht, J.; Aubert, A., 1990: Efficacy of Pygeum africanum extract in the medical therapy of urination disorders due to benign prostatic hyperplasia: evaluation of objective and subjective parameters. A placebo controlled double blind multicenter study. Wien Klin Wochenschr 102: 667-673.
3. Bassi, P.; Artibani, W.; Deluca, V.; Zattoni, F.; Lembo, A., 1987: Standardized extract of Pygeum africanum in the treatment of benign prostatic hypertrophy. Minerva Urology Nefrology 39: 45-50.

4. Becker, H.; Scher, J. M.; Speakman, J. B.; Zapp, J., 2005: Bioactivity guided isolation of antimicrobial compounds from Lythrum salicaria. Fitoterapia 76:580-584 http://dx.doi.org/10.1016/j.fitote.2005.04.011.

5. Bombardelli, E.; Morazzoni, P., 1997: Prunus africana (Hook. f.). Kalkm Fitoterapia 68: 205-218.

6. Breza, J.; Drurny, O.; Borowka, A.; Hanus, T.; Petrik, R.; Blane, G.; Chadha-Boreham, H., 1998: Efficacy and adaptability of Tedenan (Pygeum africanum) in the treatment of benign prostatic hyperplasia (BPH): a multicenter trial in central Europe. Current Medical Research Opinion 14: 127-139 http://dx.doi.org/10.1185/03007999809113352.

7. Catalano, S.; Ferretti, M.; Marsili, A.; Morelli, I., 1984: New constituents of Prunus africana bark extract. Journal of Natural Products 47(5): 910 http://dx.doi.org/10.1021/np50035a039.

8. Deepak, M.; Handa, S. S., 2000: Anti-inflamatory activity and chemical composition of extract of Verbena officinalis. Phytother 14: 463-465. (Short communication) http://dx.doi.org/10.1002/1099-1573(200009)14:6<463:: AID-PTR611>3.3.CO;2-7.

9. Dufour, B.; Choquenet, C.; Revol, M.; Faure, G.; Jorest, R., 1984: Controlled study of the effects of Pygeum africanum extract on the functional symptoms of prostatic adenoma. Ann Urol (Paris) 18: 193-195.

10. Escalente, M. A.; Santecchia, C. B.; Lopez, S. N.; Gattuso, M. A.; Ravelo, A. G.; Monache, F. D.; Sierra, M. G.; Zacchino, S. A., 2002: Isolation of antifungal saponins from Phytolacca tetramera, an Argentinean species in citric risk. Journal of Ethnnopharmacology 82: 29-34 http://dx.doi.org/10.1016/S0378-8741(02)00145-9.

11. Hitimana, J., 2000: Variations in structure, composition and regeneration within the Mt Elgon moist lower montane forest, Kenya. MPhil Thesis, Moi University, Eldoret, Kenya.

12. Mburu, F., 2007: Study and valorization of different Kenyan wood species. Ph.D Thesis, Universitè Henri Poincarè, Nancy-1, France.

13. Neya, B.; Mohamed, H.; Mathieu, P.; Gérardin, P., 2004: On the durability of Burkea africana heartwood: evidence of biocidal and hydrophobic properties responsible for durability. Annals of Forest Science 61(3): 277-282 http://dx.doi.org/10.1051/forest:2004020.

14. Stewart, A. P.; Ripley, P. H.; Hoegedal, P.; Klein, U., 2003: Investigation of diverse reactions following the use of Econor in pigs. Journal of Veterinary Pharmacology and Therapeutics 26:253.

\section{Corresponding address:}

Lecturer PETER SIRMAH, Ph.D.

Department of Forestry and Wood Science Department, Chepkoilel University College

Moi University

P.O. Box 1125-30100

Eldoret, KENYA

e-mail:sirmahkipkosgei110@hotmail.com 